\title{
Neonatal retinoblastoma: a brief report from the Malaysian Retinoblastoma Registry
}

Zayani Zohari, Variant Chee Nee Vern, Li Yen Chan, Jamalia Rahmat

Department of Ophthalmology, Hospital Kuala Lumpur, Ministry of Health, Malaysia

\section{Abstract}

Neonatal retinoblastoma is more widely reported in developed countries than in developing countries. We have conducted a retrospective case series to understand the nature of neonatal retinoblastoma in Malaysia due to lack of data from developing countries.

A retrospective record review of 295 patients was conducted from the Retinoblastoma Registry on the National Eye Database (NED) between January 2005 and December 2019. Six out of 295 patients (2.03\%) were identified as neonatal retinoblastoma in Malaysia from 2005 until 2019 compared to developed countries, in which the detection rate were 3.5 to 10 times higher.

Lack of awareness among survivor parents about the risk of their newborns developing retinoblastoma in may be a contributing factor. Neonatal retinoblastoma is difficult to manage, thus close and continuous monitoring is needed in centres dedicated to retinoblastoma management.

Keywords: developing countries, familial retinoblastoma, leukocoria, neonatal retinoblastoma

Correspondence: Dr. Zayani Zohari, MD, Department of Ophthalmology, Hospital Kuala Lumpur, Malaysia.

E-mail: zayanizohari@gmail.com 


\section{Retinoblastoma neonatal: laporan ringkas dari pengkalan data Pendaftaran Pesakit Retinoblastoma di Malaysia}

\section{Abstrak}

Retinoblastoma neonatal lebih banyak dilaporkan di negara maju berbanding di negara yang sedang membangun. Kami telah menjalankan kajian siri kes retrospektif untuk memahami retinoblastoma neonatal di Malaysia kerana kekurangan data dari negara-negara membangun.

Kajian rekod retrospektif terhadap 295 pesakit dilakukan dari pengkalan data National Eye Database (NED) pada pendaftaran pesakit Retinoblastoma di antara Januari 2005 dan Disember 2019. Enam daripada 295 pesakit (2.03\%) dikenal pasti sebagai retinoblastoma neonatal di Malaysia dari tahun 2005 hingga 2019 berbanding negara maju, di mana kadar pengesanannya adalah 3.5 hingga 10 kali lebih tinggi.

Di antara faktor penyumbang adalah kurangnya kesedaran di kalangan ibu bapa kanser survivor mengenai risiko bayi baru lahir mereka menghidap retinoblastoma. Retinoblastoma neonatal sukar dikendalikan, oleh itu pemantauan rapi dan berterusan diperlukan di pusat-pusat yang dikhaskan untuk merawatretinoblastoma.

Kata kunci: leukocoria, negara membangun, retinoblastoma keluarga, retinoblastoma neonatal

\section{Introduction}

Retinoblastoma is the most common intraocular malignancy that affects children, but it is rarely detected in neonates. ${ }^{1,2}$ Neonatal retinoblastoma is diagnosed in infants younger than 28 days of life or in case of preterm birth, less than 44 weeks of gestational age. ${ }^{1}$ Although previous studies in developed countries have demonstrated that neonatal retinoblastoma is a subgroup that behaves differently from a clinical standpoint, data from developing nations are lacking. ${ }^{3,4}$ Therefore, the aim of this retrospective case series was to report Malaysia's perspective of neonatal retinoblastoma. 


\section{Materials and methods}

Medical Research and Ethics Committee (MREC) of Ministry of Health, Malaysia approval was obtained. A retrospective record review of 295 patients was conducted from the Retinoblastoma Registry on the National Eye Database (NED) between January 2005 and December 2019. Six patients were identified as having neonatal retinoblastoma. Data obtained from the registry and hospital medical records include age at presentation, gender, ethnic group, family history, laterality, stage of ocular disease at presentation, mode of treatment, tumour recurrence, globe salvage, and patient death.

\section{Results}

Six patients (12 eyes) were identified as having neonatal retinoblastoma, comprising $2.03 \%$ of all the retinoblastoma found in the registry (Table 1 ).

\section{Patient demographics}

Five patients were born at term and one patient was a preterm infant. The mean age at diagnosis was 26 days for the full-term babies (range: $21-28$ days), while the diagnosis of the preterm infant was made at 34 weeks corrected gestational age. Four were males and two were females. There were two Malays, three Chinese, and one Indian. Out of the six patients, two were siblings who had a positive family history of retinoblastoma. Four patients presented with leukocoria, while one patient was screened for familial retinoblastoma at 28 days of life. The premature neonate was diagnosed to have retinoblastoma during routine retinopathy of prematurity screening.

\section{Tumour characteristics and staging}

The eyes were classified according to the International Intraocular Classification of Retinoblastoma (IIRC) into Group A $(n=2)$, Group B $(n=5)$, Group C ( $n=0)$, Group D $(n=0)$, and Group $\mathrm{E}(n=5)$. Of the six children, two presented initially with unilateral disease but subsequently progressed to bilateral involvement. The first patient had a Group E tumour in the first involved eye and later developed a Group B tumour in the other eye eight months later. The second patient was diagnosed to have a Group B tumour in one eye before later developing a Group A tumour in the fellow eye nine weeks later. Only one child had advanced disease (Group E) in both eyes. Three other children had advanced disease (Group E) in one eye and less advanced disease (Group B) in the fellow eye. Two other patients had less advanced disease in both eyes. Eight eyes had macular involvement, with four patients having macular involvement in one eye and two patients having macular involvement in both eyes. 


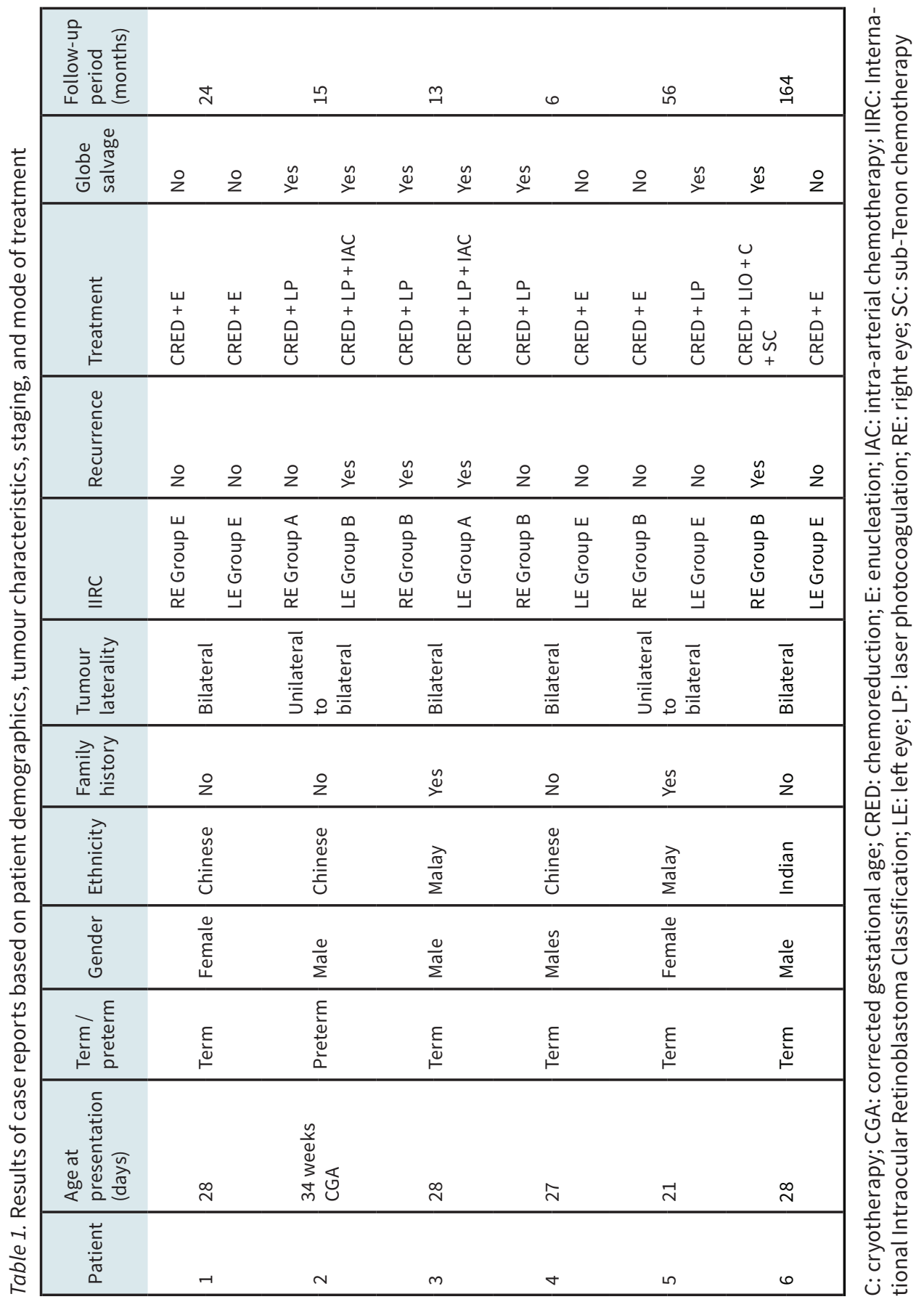




\section{Mode of treatment}

All the patients received systemic chemotherapy and locally directed therapies, such as laser photocoagulation and cryotherapy, to help manage the smaller tumours. Two of the patients required multiple intra-arterial chemotherapy (IAC) for new tumours that developed after systemic chemotherapy. One patient had multiple local injections of chemotherapeutic agents via the sub-Tenon route as an adjuvant to systemic chemotherapy.

\section{Tumour recurrence}

Tumour recurrence was seen in three patients (four eyes) in the form of new tumours after completion of systemic chemotherapy. All the patients developed solid tumour recurrence within the chorioretinal scars of treated retinoblastoma tumours (Fig 1). The mean duration for recurrence was 2.6 months after completion of systemic chemotherapy (range: 2-4 months). Three eyes developed recurrence within the macula.

\section{Outcome}

Of the 12 eyes with retinoblastoma, 5 eyes were enucleated as the eyes were staged to have Group E tumours. One patient had both eyes enucleated after three cycles of chemotherapy due to the advanced stage of Group E retinoblastoma.

Three patients with Group E retinoblastoma in one eye underwent enucleation before systemic chemotherapy were initiated. Histopathology findings confirmed the diagnosis of retinoblastoma with the presence of rosettes with no histopathological risk factors for extraocular extension. In the patient who underwent bilateral enucleation after chemotherapy, the histopathology findings showed shrunken orbit with intraocular necrotic tissue occupying almost the entire posterior segment up to the anterior chamber.

Ocular salvage was achieved in 7 eyes (58.3\%) over a mean follow-up period of 42.3 months (median: 15 months; range: 6-164 months). No patients died during follow-up. No secondary malignancies or metastatic disease was seen until the last follow-up.

\section{Discussion}

Prior reports in developed countries showed that $7-10 \%$ of retinoblastoma is diagnosed in the neonatal period. ${ }^{1}$ Our series demonstrated that $2.03 \%$ of retinoblastoma is diagnosed in neonates. According to a recent series from LV Prasad Eye Institute in India, a national referral centre for retinoblastoma in India, their results were similar to ours: < $1 \%$ of neonatal retinoblastoma was detected from 2006 to $2017 . .^{5}$ These data indicate that detection of neonatal retinoblastoma is 3.5 to 10 times more frequent in developed countries. The reason for this disparity is mul- 

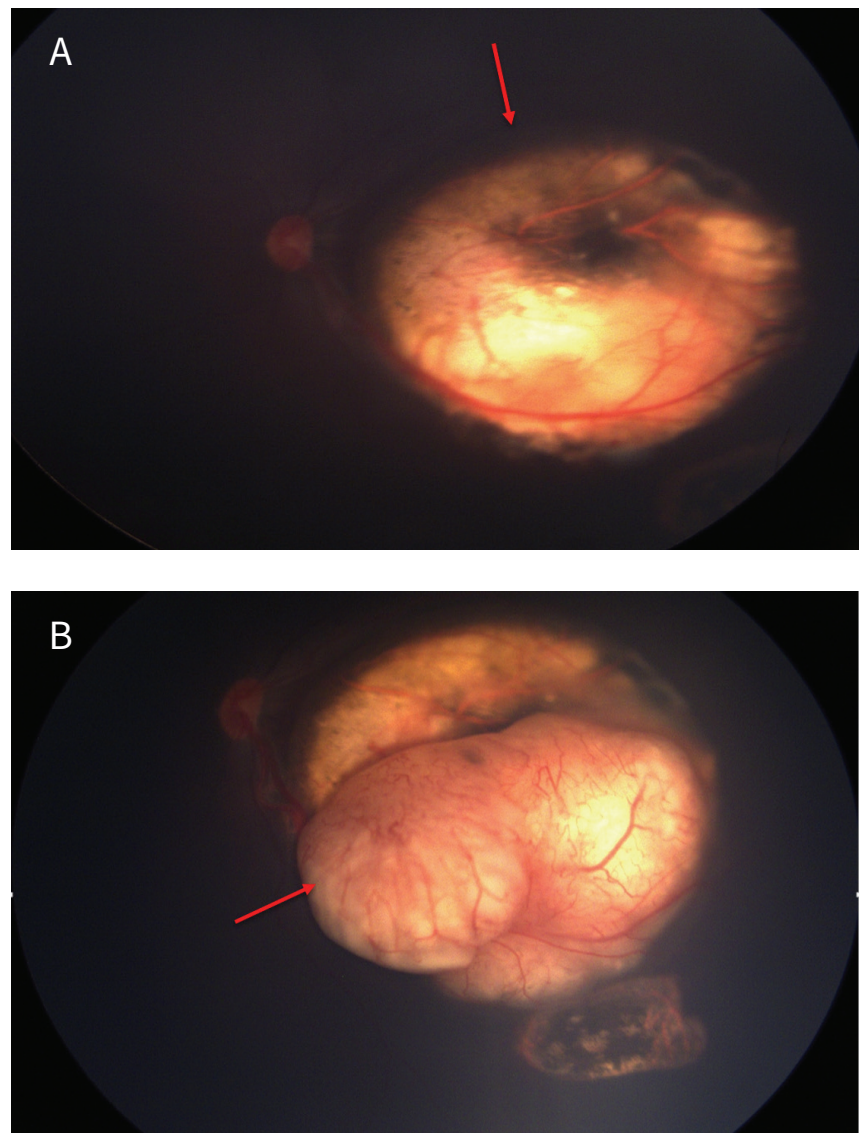

Fig. 1. (A) Left eye fundus photo taken with RetCam shows flat scar with calcification (red arrow) after completing systemic chemotherapy and laser photocoagulation treatment. $(B)$ Left eye fundus shows recurrence within the chorioretinal scar (red arrow) of treated retinoblastoma tumour after ten weeks.

tifactorial, including delayed diagnosis of retinoblastoma in developing countries due to poor awareness by the public and healthcare services, especially the lack of awareness among survivor parents about hereditary malignancy.

As seen in our series, leukocoria exceeded positive family history as the most common reason for detection of neonatal retinoblastoma. On the other hand, a series performed in developed countries showed screening prompted by positive family history as the main factor for detection (44\% to $71 \%)$., ${ }^{1,3}$ This can be explained by the fact that there are many more cases of familial retinoblastoma in developed countries compared to developing countries, where medical resources are limited and survivors with familial retinoblastoma are more rarely seen. ${ }^{2}$ Leukocoria is also 
quite common as a presenting feature in neonatal retinoblastoma, especially in those with no positive family history, which is suggestive of sporadic occurrence of retinoblastoma. ${ }^{1,3}$ Interestingly a premature baby was diagnosed to have neonatal retinoblastoma during routine retinopathy of prematurity screening. A recent meta-analysis performed to evaluate the impact of prematurity on retinoblastoma showed that data was insufficient to conclude whether premature birth has an impact on the development of retinoblastoma. ${ }^{6}$ A common characteristic of neonatal retinoblastoma is that unilateral disease at the time of diagnosis is common, but it has a very high rate of becoming bilateral. ${ }^{1,3,7}$ In a study of 46 children with neonatal retinoblastoma, 26 (57\%) had unilateral involvement, of which 22 (85\%) eventually developed bilateral disease. ${ }^{3}$ Our results showed that two of the patients presented with unilateral disease at diagnosis, but eventually developed bilateral involvement less than a year later, while the remaining four patients presented with bilateral disease. This is essential for advising and guiding parents about the importance of regular fundus screening for early and accurate detection of tumours in the otherwise normal eye for timely treatment and better outcomes. Although only two of the patients had a history of familial retinoblastoma in the parent, germline mutation is suggestive for the rest, as they also had bilateral disease.

Multiple studies conducted in developed countries have established that screening for retinoblastoma in babies with positive family history of retinoblastoma usually has less advanced grouping of retinoblastoma with the presenting eye usually having a Group B tumour while the fellow eye will typically have a Group A tumour because of short screening intervals after diagnosis of the first eye. ${ }^{1}$ This can be clearly seen in two of the patients in our series that were diagnosed to have neonatal retinoblastoma from fundus screening. Interestingly, the patients in our series that presented with leukocoria has more advanced disease. All but one patient presented with one eye having Group E tumours while one patient presented with both eyes having Group E tumours.

As patients with neonatal retinoblastoma present at such a young age, the chances of macular involvement are high. ${ }^{1}$ This is because tumour location in relation to retinal topography varies with age of diagnosis. This relationship follows a central-to-peripheral distribution, with macular tumours presenting earliest and anterior tumours presenting last. ${ }^{3}$ These findings are supported by our study. All the patients in our series presented with at least one eye with macular involvement under the assumption that patients with large tumours filling most of the globe (Group E) have macular involvement. Of the six patients in our series, two patients had bilateral macular involvement, and four patients had unilateral macular involvement with the contralateral eye having extramacular tumours.

In retinoblastoma, treatment is dependent on the laterality and symmetry of disease. In our series, all the patients required systemic three-agent chemotherapy consisting of carboplatin, vincristine, and etoposide, except for two relatively younger patients who were administered two-agent chemotherapy, consisting of 
carboplatin and vincristine alone, due to the leukogenic concerns of etoposide. ${ }^{4}$ Despite undergoing systemic chemotherapy and locally directed therapies when the need arose, $33.3 \%$ of eyes in our series developed recurrence after completion of systemic chemotherapy. In another study, tumour relapse was noted to be $44 \%$ of eyes. ${ }^{5}$ The tendency for local relapse is a commonality of neonatal retinoblastoma, which quite often develops new tumours after or during systemic chemotherapy. The reasons speculated for the failure of systemic chemotherapy and locally directed therapies are the lack of vascular supply in smaller tumours and also the lack of pigments in the neonatal retina. ${ }^{1}$ All these potential pitfalls make neonatal retinoblastoma a challenge to manage in spite of early diagnosis and earlier-than-average tumour stage.

Globe salvage rates in neonatal retinoblastoma vary from $72 \%$ to $92 \% .^{1,3}$ In our series, we were able to salvage $58.3 \%$ (7 eyes). This is because five of the eyes presented at stage Group E, requiring enucleation. This shows that early age of diagnosis does not guarantee an early stage of intraocular disease. In our series, there was no evidence of secondary non-ocular malignancies, metastatic disease, or death.

\section{Conclusion}

The management of neonatal retinoblastoma is highly complex, requiring a multidisciplinary approach and specialized centres dedicated to retinoblastoma management. We need to increase parental awareness by effectively conveying genetic information for parents of children with neonatal retinoblastoma to take advantage of prenatal or postnatal genetic testing, when available, and proper postnatal screening of familial retinoblastoma.

\section{Acknowledgements}

The authors would like to thank the Director General of Health Malaysia for the permission to publish this paper.

\section{References}

1. Kivelä TT, Hadjistilianou T. Neonatal Retinoblastoma. Asia Pac J Oncol Nurs. 2017;4(3):197-204. PMID: 28695165.

2. Chantada GL, Dunkel IJ, Qaddoumi I, et al. Familial retinoblastoma in developing countries. Pediatr Blood Cancer. 2009;53(3):338-342. doi:10.1002/pbc.21970. 
3. Abramson DH, Du TT, Beaverson KL. (Neonatal) retinoblastoma in the first month of life. Arch Ophthalmol. 2002;120:738-742.

4. Gombos DS. Retinoblastoma in the perinatal and neonatal child. Seminars in Fetal and Neonatal Medicine. 2012;17:239-242. PMID: 22622484.

5. Kaliki S, Jajapuram SD. Neonatal retinoblastoma: A study of five cases. Oman J Opthalmol. 2019;12:156-59. doi:10.4103/ojo.OJO_176_2018.

6. Paquette $\mathrm{K}$, Coltin $\mathrm{H}$, Boivin $\mathrm{A}$, et al. Cancer risk in children and young adults born preterm: A systematic review and meta-analysis. PLoS One. 2019;14(1):e0210366. doi:10.1371/journal.pone.0210366.

7. Imhof SM, Moll AC, Schouten-van Meeteren AY. Stage of presentation and visual outcome of patients screened for familial retinoblastoma: Nationwide registration in the Netherlands. Br J Ophthalmol. 2006;90:875-878. 